\title{
THE PURCHASE BY RAILROADS OF THEIR OWN OBLIGATIONS
}

\author{
ROBert T. SwaIne*
}

As this is being written, junior mortgage bonds of New York Central are selling at 45; of Illinois Central at $3^{8}$; and of Southern Pacific at 34. Even before the German hordes swept through Holland and Belgium such bonds of New York Central had not sold in excess of 84; of Illinois Central in excess of 62; and of Southern Pacific in excess of 64 for two years. These three systems were formerly regarded as among the soundest financially, and even today there seems to be no immediate peril of their bankruptcy. They have been mentioned here merely as nation-wide illustrations of the depth to which railroad credit has sunk. Numerous other similar illustrations could be given.

One mathematically minded is irresistibly tempted to sharpen his pencil and do a bit of figuring when he sees, let us say, $\$ 100,000,000$ of outstanding $5 \%$ mortgage bonds of the $X$ System ranging during recent years between 25 and 40 , while the federal government is borrowing money with the payment of practically no interest and lending it broadeast at low rates. This figuring has produced the mathematical conclusion that by borrowing around forty million dollars from the government at, say, $4 \%$ to buy up such an issue the $X$ System would reduce its fixed charges by nearly three and a half million dollars.

This simple mathematical conclusion has intrigued not only the amateur cconomists and railroad reorganizers but even such governmental representatives as officers of the Reconstruction Finance Corporation and members of both Houses of Congress, and, as well, such presumably hardheaded businessmen as the bankers and industrial executives who make up the membership of the National Conference of Investors.

The idea has been crystalized in proposed legislation to authorize the making by Reconstruction Finance Corporation of loans to railroads to enable them to purchase their outstanding obligations in order to reduce their fixed charges. This proposed legislation has had the support both of Reconstruction Finance Corporation and the National Conference of Investors, and is embodied in the so-called Omnibus Bill

- Ph.B., 1905, State University of Iowa; LL.B., 1910, Harvard University. Member of the New York Bar. Member of the firm of Cravath, de Gersdorf, Swaine \& Wood. Director and Counsed to Board, Chicago, Milwaukee, St. Paul \& Pacific R. R. Contributor to legal periodicals on problems of corporation and corporate reorganization law. 
(S. 2009) reported favorably to the two Houses of Congress by the Conference Report of April 26, 1940 .

The idea behind the proposed legislation is not something new, the product of this depression decade. Much the same scheme was suggested by a group of securityholders in connection with the Chicago, Milwaukee \& St. Paul reorganization of 1925-rg28. It was there suggested that a large fund should be raised by assessment of stockholders for retirement of bonds then selling at around 50. For the reasons which are developed below in the discussion of the present proposals, the suggestion was not regarded as of any practical value.

While undoubtedly some reduction in railroad fixed charges could be accomplished over a period of time by the government loans now suggested for purchases of railroad obligations, the difficulties in the way of any substantial accomplishment have been much underestimated and the probable results much overestimated.

The present levels of railroad obligations are not the result of any flood of selling by railroad bondholders. Many of the stronger holders, particularly banks and insurance companies, hold their railroad bonds against their own dollar obligations of not immediate maturity. Accordingly, so long as there is any reasonable hope that the bonds will be paid at maturity, or will approximate their original purchase price before maturity, such holders are not anxious to sell their bonds. Indeed, it is one of the.anomalies of the situation that for such holders many railroad bonds, at their present low prices, constitute a hedge against inflation. While public utilities are sufferers from inflation at the outset, ultimately rates and costs adjust themselves to the inflation, with the result that at some point in an inflation the bonds of many roads now selling at large discounts would probably sell at their principal amount.

From the technical market aspect of the problem, present low prices of railroad bonds are due to a lack of buyers in a thin market. This lack of buyers is, of course, due to lack of confidence in railroad credit. Nevertheless it is believed that were 2 buyer to appear prepared to purchase any large amount of an outstanding issue of any carrier comparable to the three which have been mentioned, the amount of bonds which he could obtain at present prices would be negligible as compared with the total amount of the issue. Indeed, once it were known that such a buyer was in the market even discouraged bondholders who are selling at present prices would tend to take courage and increase the level at which they would be willing to sell. It would require a very carefully managed market operation, with complete disregard for the philosophies of the Securities and Exchange Commission, to accumulate any substantial fraction of the total of any of today's low priced railroad obligations at prices approximating those now prevailing.

A further practical difficulty lies in the unwillingness expressed by responsible public officials that government money should be employed in such buying projects except in association with private money and then, it is suggested, on terms by which the government money should be preferred over the private money in the venture. There can be no criticism of the government for taking this attitude. Indeed, it 
may well be questioned why the government should make to private enterprise the large loans which the idea contemplates. Perhaps the answer, not wholly satisfying, is that if every other kind of pressure group has its feet in the public trough, why shouldn't the railroad investors get in too.

Assuming, however, that a government institution were willing to make the proposed loans on terms of such priority, where could any private investors be found to supply the subordinated funds for the purchase? If, as is the basic idea of the suggestion, the bonds are to be purchased for the benefit of the railroad debtor, not for the benefit of those who put up the money, and if the railroad to which the loans are made is to be required to repay only the amount of the loan (and indeed that with comparatively low interest), obviously there can be no profit for the lenders above the purchase price. On the other hand, the very fact of the low prices of the bonds proposed to be purchased demonstrates the serious risk of loss in the venture. Why should any bank or private investor go into any such project on any basis, let alone a subordinated basis, even if already heavily committed in bonds of the carrier to which the loan was proposed to be made? If the private investor wants to invest in additional bonds he will buy them outright and have the opportunity for a profit at much less risk of loss than that to which he would be subject by contributing to 2 joint government-private loan in which his contribution would be subordinated to that of the government.

Were this scheme for buying up low-priced railroad obligations through government aid ever to get substantially further than the superficial theorizing which has heretofore prevailed, the responsible government officials might well question whether the considerations affecting private investors mentioned in the next preceding paragraph would not also affect the government investment. If the credit of our railroads under private ownership and operation does not afford sufficient hope to lift the prices of New York Central, Illinois Central or Southern Pacific bonds above their present levels it may be that ultimate public ownership and operation is inevitable. If so, might not the government better purchase outright such bonds as it can pick up at low prices rather than take them as collateral for a loan of their purchase price?

This latter thought leads to a consideration of what is proposed to be done with the purchased bonds once they are purchased with the proposed loan. Obviously if they are not so cancelled that they can never again become obligations of the carrier which issued them and to which the loan is made, the fixed charges of the debtor may not have been reduced. This point has largely been overlooked in the discussion of the proposed legislation. At least it has been overlooked by most of the protagonist investors; perhaps not by Reconstruction Finance Corporation, for the suggested legislation has contemplated that the purchased bonds shall be kept alive and pledged as collateral for the loan. Furthermore, this legislation contemplates that Reconstruction Finance Corporation, as the lender, and any purchaser from it of the loans, shall have the right, even after bankruptcy or receivership of the borrower, to sell 
the pledged obligations in the event of any default on the loan and to become absolute owner of such obligations.

An understanding of the problem thus presented requires consideration of the legal effect of the pledge by a debtor of its own obligations as collateral to an obligation evidencing a loan. The legal implications of such a pledge are widely misunderstooc. The subject is highly technical, but the law governing it was settled long before the enactment of Section 77 of the Bankruptcy Act, under which most railroad reorganizations are now being effected.

If the $X$ System issues its promissory note for $\$ 1,000,000$ to evidence a loan of that amount, and to secure the note pledges $\$ 2,000,000$, principal amount, of its own bonds, it has created only one debt, viz., the promissory note. ${ }^{1}$ In other words, the debt is but $\$ 1,000,000$, not $\$ 3,000,000$. This is true whether the $\$ 2,000,000$ of pledged bonds are for the first time "issued" by the pledgor as a part of the pledge, or whether they are so-called treasury bonds, i.e., bonds previously issued but theretofore repurchased by the pledgor, or whether they are purchased with the proceeds of the loan. In the latter event, their repurchase by the issuer exinguishes them as debt. This is also true whether the pledged bonds are secured or unsecured.

So long as no receiver or trustee is appoinied of the pledgor's property or any other creditor proceeding designed to crystalize the rights of all the creditors has been instituted, the effect of the pledge is to give the pledgee a power of attorney to issue the pledged securities by sale in enforcement of the pledge. Upon such a sale the debt of the pledgor is increased by an amount dependent upon the proceeds of the sale of the pledged bonds. For example, if in the case above put, the pledgee sells the $\$ 2,000,000$ of pledged bonds for $\$ 75^{0,000}$, the pledgor then has outstanding $\$ 2,250,000$ of debt, viz., the $\$ 2,000,000$ of pledged bonds which have now been sold, plus the $\$ 250,000$ deficiency on the promissory. note. This again is true whether the pledged bonds be secured or unsecured.

When, however, the pledgor becomes the object of any legal proceeding designed to crystalize the rights of its creditois inter se, the pledgee is no longer entitled to sell the pledged bonds." An injunction will issue against any such disposition of the pledged bonds by the pledgee. It is believed, however, that an injunction is necessary only for the purpose of preventing the creation of a cloud upon the pledgor's property through the claim of a lien or other right in the pledgor's property by the purehaser of the pledged bonds upon the purported enforcement of the pledge. Unless the purchaser at the pledgee's sale were a bona fide purchaser for value without notice of the equities of the other creditors as against the pledged bonds (which, as a practical matter, is unlikely), such a purchaser would not seem to have, even in the absence

\footnotetext{
${ }^{2}$ Merrill v. National Bank of Jacksonville, 173 U. S. I3I (1899); Mfississippi Valley Trust Co. v. Railway Sted Spring Co., 258 Fed. 346 (C. C. A. 8th, I919); Washington-Alaska Bank v. Dexter Horton Nat. Jank, 263 Fed. 304 (C. C. A. 9th, 1920); Worth v. Marshall Field \& Co., 240 Fed. 395 (C. C. A. 4th, 1917); Butterfield v. Woodman, 223 Fed. 956 (C. C. A. Ist, I915); Fitner v. Dianiond States Sted Co., 176 Fed. 384 (C. C. Del., 1910).

Mississippi Valley Trust Co. v. Kailway Steel Spring Co., supra note I; Continental Illinois Nat. Bank \& Trust Co. v. Chicago, R. I. \& P. Ry, 294 U. S. 648 (1935).
} 
of an injunction, any greater rights than the pledgee himself. Obviously it would be inequitable as between creditors to permit one creditor to increase the "debt" of the insolvent to him after the estate of the debtor had been marshaled for distribution among all creditors.

If the pledged bonds are unsecured obligations of the pledgor it has long been well settled that the pledge is wholly nugatory in the enforcement of the rights of the pledgor's creditors inter se. The pledgee can prove against the pledgor's estate only for the debt, viz., the principal amount of the promissory note, and cannot prove for anything in respect of the pledged bonds.?

If, however, the pledged bonds are obligations secured by lien upon the pledgor's property, the pledgee does have rights in that property arising out of the pledged bonds. But those rights are not by way of creating the nominal amount of the pledged bonds the debt of the pledgor. The only debt in the assumed situation still remains the promissory note. But the effect of the pledge of the bonds is to give to the pledgee, as security for that debt, that proportion of the mortgage securing the pledged bonds which their nominal amount bears to the total nominal amount of the bonds outstanding under that mortgage. The pledgee under such circumstances may receive distribution of the value of the mortgaged property in enforcement of the mortgage in that proportion, but only up to an amount which will equal the tctal debt to him, viz., the amount of the claim on the promisory note. He may also prove on the promissory note either for the fuil amount if the proceeding is in equity, or for the deficiency if the proceeding is in bankruptcy, subject, however, to the limitation that his total recovery, whether upon the promissory note or upon the mortgage, shall not exceed the amount of the debt

Pursuing the above illustration further, if the pledged bonds were part of a total issue of $\$ 10,000,000$, and the mortgaged property sold for $\$ 5,000,000$, the pledgee, out of the mortgaged property, would be entitled to one fifth of the proceeds, or $\$ 1,000$,$\infty$, thus extinguishing the debt on the promissory note except for any unpaid interest or other costs included in the dett under its terms. If in this assumed case the mortgaged property sold for $\$ 7,000,000$, the pledgee would not be entitled to retain the full one fifth of the proceeds, as owner of the pledged bonds, but would be limited to the amount of the proceeds of the mortgaged property sufficient to satisfy the debt on the promissory note. The remainder of the one fifth of the pro-

- Union National Bank v. Pcople's Savings \& Trust Co., 28 F. (2) 326 (C. C. A. 3rd, 1928); Firrt National Bank of Beaumont v. Eason, 149 Fed. 204 (C. C. A. 5th, 1906; Curtis v. Walpole Tire \& Rubber Co., 227 Fed. 698 (D. Mass., 1915); Third Avenue National Bank v. Eastern R. R. Co., 122 Mass, 210 (1877); People 8. Remington \& Sons, 54 Hun. 480, 8 N. Y. Supp. 31 (1889) affd, I21 N. Y. 676, 24 N. E. 1095 (1889); Dibert v. D'Arcy, 248 Mo. 617, 154 S. W. 1116 (1913).

- Merrill v. National Bank of Jacksonville, 173 U. S. 131 (1899); Hitner v. Diamond States Steel Co, 176 Fed. 384 (C. C. Del., 1910); Rississippi Valley Trust Co. v. Railway Steel Spring Co., supra note x; Washingron-Alaska Bank v. Dexter Horton Nat Bank, supra note I; Worth v. Marshall Ficld \& Con, supre note 1; Butterficld v. Woodman, supra note I; American Brakeshoe \& Foundry Co. v. New York Railways, 277 Fed. 26I (S. D. N. Y., 1921); Atlantic Trust Co. v. Woodbridge Canal \& Irrigation Co, 86 Fed. 975 (C. C., N. D. Cal., 1897); Equitable Trust Co. v. Great Shoshone \& Twin Falls Water Power Co., 228 Fed. 516 (D. Idaho, 1915); Simmons v. Taylor, 23 Fed. 849 (C. C., S. D. Iowa, 1885), app. dismissed, 127 U. S. 52 (1887); Claflio v. South Carolina Railroad Co., 8 Fed. 118 (C. C., S. C, 1880). 
ceeds would fall into the other four fifths for satisfaction of the claims of the holders of the other $\$ 8,000,000$ of outstanding bonds.

The practical effect of these well-established common law rules is that under the law, as it has heretofore stood, a pledgor, whether an individual, a bank, or the Reconstruction Finance Corporation, is not entitled, in a Section 77 reorganization, either to sell pledged collateral constituting the pledgor's own obligations or, upon reorganization, unconditionally to take the new securities issuable against the pledged bonds as owner. The pledgee may take such new securities as owner only if their value is clearly less than that of the loan. Even then it may be that the pledgee is fairly entitled, as against other creditors, only to receive such new securities as collateral for some new obligation representing the loan. Particularly may this be true if the value of the pledged securities approximates, or perhaps exceeds, the amount of the loan. Just how to treat such collaterally secured obligations has been one of the most difficult problems with which the Interstate Commerce Commission has had to deal in reorganizations under Section 77. It has been clear, however, that under existing law pledgees do not now have rights as "absolute owners" of pledged collateral.

If, therefore, legislation were designed to enable railroads to reduce their fixed charges through purchase of their outstanding obligations by collateral loans from Reconstruction Finance Corporation on the basis of the present established law regarding such collateral loans, the borrowing carriers, and investors in their securities, would get the benefit of a reduction in fixed charges by the difference between the charges on the purchased securities and the charges on the new loan, provided the borrower either (a) remained solvent so that the loan could ultimately be paid off and the pledged securities retired, or (b) went into receivership or bankruptcy before Reconstruction Finance Corporation (or any other pledgee-lender or transferce thereof) sold out the pledge. On the other hand, if the pledgee should sell out the pledged collateral after a default on the loan and while negotiations were under way to obviate a reorganization or bankruptcy, other investors in the pledgor-borrower carrier would be materially injured through the resultant increase in the outstanding. debt of the borrower.

-It may well be that the potential benefits of such arrangements outweigh the risks of an adverse result to the borrowing railroad or its investors. However, none of the bills which have been introduced for the purpose of authorizing loans by Reconstruction Finance Corporation for the purpose of effecting reductions of fixed charges through schemes of the sort hereunder discussion has contemplated that the loans and pledges should be made upon existing common law terms. All the bills under discussion in Congress, including S. 2009 approved by a Conference Report, have purported to create in Reconstruction Finance Corporation, and any purchaser of such a loan obligation from it, rights wholly in conflict with those under existing law respecting such obligations. For example, S. 2009 , in that portion thereof dealing with this subject matter, provides that 
... the title of any owner of a collateral note evidencing a loan to a railroad, ... and the right of any such owner to acquire title to the collateral securing such note, free and clear of any equity of redemption, . and thereafter to deal with the same as the absolute owner thereof, shall not be affected, restricted, or restrained by or pursuant to [the Bankruptcy Act or] by or pursuant to any other provision of law applicable to any proceedings thereunder.

If (as may be doubtful) such an enactment were effective, this would mean that if Reconstruction Finance Corporation made a loan of $\$ 1,000,000$ to enable a railroad to purchase $\$ 2,000,000$ of its mortgage bonds, which were in turn pledged to secure the loan, and the borrower thereafter underwent reorganization, Reconstruction Finance Corporation or its transferee could sell out the $\$ 2,000,000$ of pledged bonds, which would then be selling at discounts much greater even than those prevailing at the time of their purchase, and would presumably purchase them itself. If the $\$ 2,000,000$ of pledged bonds were selling at $10 \%$ of their par value (which is typical of roads now in bankruptcy) this provision would purport to increase the debt of the borrower, for purposes of determining the rights of the creditors inter se, from the $\$ 1,000,000$ loan to the $\$ 2,000,000$ of pledged bonds plus the $\$ \$ 00,000$ deficiency in the loan. In other words, on the illustration given, the borrowing carrier and its existing investors would, under such legislation, be worse off than they are today by $\$ 800,000$.

Necessarily, most of the loans made under any such legislation would be made to railroads whose securities are selling at heavy discounts, indicating serious risk of ultimate bankruptcy. It would therefore seem that even with respect to new loans hereafter made under such legislation the probability of injury to investors would so exceed the probability of benefit as to make it unwise from the standpoint of any railroad investors that such loans be made.

This provision of S. 2009 , however, in its present form and as contained in carlier bills covering the subject matter, goes much further. For example, S. 2956, an carlier bill containing the language above quoted, contained a provision (which can hardly be characterized otherwise than as a "joker") designed to give to Reconstruction Finance Corporation rights which it does not now have, in respect of loans heretofore made by it to railroads which subsequently went into bankruptcy and which in no probability could obtain any benefits from the proposed legislation. In that bill the purported enlargement of the existing legal rights with respect to pledges made to Reconstruction Finance Corporation was not limited to loans "hereafter made by" Reconstruction Finance Corporation but was extended to loans "heretofore . . . made by" Reconstruction Finance Corporation. Such loans are now outstanding in almost .every railroad bankruptcy situation. To grant to Reconstruction Finance Corporation, or anyone to whom it may sell the notes evidencing loans heretofore made to these now bankrupt railroads, the right to become the absolute owner of the pledged obligations (and hence of the new securities issuable against them in the reorganization) irrespective of their value, was obviously a gross discrimination against (1) other holders of collateral notes of the same bankrupts similarly secured, whether banks or other institutions, who did not have any such rights as those purported to be given 
to Reconstruction Finance Corporation, and (2) holders of bonds of the issue of which the pledged bonds were a part, who thus, by ex post facto legislation, would have their own securities diluted by a flood of collateral at outrageous discounts.

When this discrimination was brought home to the Conference Committice of Congress considering the proposed legislation, this unfair discrimination was somewhat modified, but not entirely eliminated, in S. 2009. That bill purports to give the enlarged rights in respect of collateral to any holder of a collateral note evidencing a loan from Reconstruction Finance Corporation "to a railroad not now in receivership or involved in proceedings under Section 77 of the Bankruptcy Act." In other words, while S. 2009 has eliminated the unfair discrimination contemplated by S. $295^{6}$ in favor of Reconstruction Finance Corporation loans to such roads as Frisco, New Haven, Milwaukee and Chicago North Western, which are now actually in bankruptcy, it purports to effect the same unfair discrimination in favor of Reconstruction Finance Corporation loans heretofore made to such railroads as Baltimore \& Ohio (which has just undergone a capital readjustment under a section of the Bankruptcy Act other than Section 77), Lehigh Valley (which is in such a readjustment proceeding and nevertheless now hovering on the verge of Section 77 ), and many other railroads whose precarious situation is evidenced by the low prices at which their securities are now selling.

There seems to be no possible justification for any such attempted enlargement of the rights of Reconstruction Finance Corporation ex post facto, either in any benefit which investors might obtain from loans to other railroads by Reconstruction Finance Corporation under the new legislation or on any broad principle of fairness, whether or not technically supported by conventional rules of equity. If, as seems likely, S. 2009 is to be returned to Conference on account of other provisions, the Conference Committee should delete this provision purporting to grant to Reconstruction Finance Corporation discriminatory rights in connection with loans heretofore made on the basis of the existing law. It may well be doubted that such a substantial change in the substantive rights of creditors inter se can be accomplished under our Federal Constitution by such ex post facto legislation. However, previously accepted principles of constitutional law, at least in so far as they may affect property rights coming inte conflict with some assumed theory of public interest, have in recent years been thrown into such a state of uncertainty that affected railroad investors should not remain indifferent to these discriminatory provisions of S. 2009 merely on the theory that they are unconstitutional by previously accepted standards.

If reduction of fixed charges is to be the real objective of any such legislation as that under consideration, the purported grant of discriminatory rights in favor of loans by Reconstruction Finance Corporation or any other governmental agency should, at least, be limited to loans hereafter made under the authorizing legislation. Indeed any such legislation should expressly contemplate the cancellation of the purchased bonds except for the sole purpose of evidencing, as security for the contemplated loans, the proportionate interest of the purchased bonds in the mortgage under which they are issued. 